Penelitian

\title{
Deteksi Antibodi terhadap Virus Newcastle Disease pada Burung Trucukan (Pycnonotus goiavier)
}

\author{
(Detection of Antibodies Against Newcastle disease Virus \\ in Trucukan Bird (Pycnonotus goiavier))
}

\author{
Erina', Hanni Aninaidu ${ }^{2}$, Zuhrawaty³, Etriwati', Abdullah Hamzah³, Mahdi Abrar', M. Daud AK' \\ 'Laboratorium Mikrobiologi Fakultas Kedokteran Hewan Universitas Syiah Kuala \\ ${ }^{2}$ Program Studi Pendidikan Dokter Hewan Fakultas Kedokteran Hewan Universitas Syiah Kuala \\ 3 Laboratorium Klinik Fakultas Kedokteran Hewan Universitas Syiah Kuala \\ ${ }^{4}$ Laboratorium Patologi Fakultas Kedokteran Hewan Universitas Syiah Kuala \\ *Penulis untuk korespondensi: erina@unsyiah.ac.id \\ Diterima 29 Maret 2021, Disetujui 23 September 2021
}

\begin{abstract}
ABSTRAK
Burung trucukan (Pycnonotus goiavier) merupakan salah satu burung liar yang sering dipelihara karena kicauannya yang merdu. Infeksi ND dapat berupa infeksi yang akut atau kronis yang menyerang burung trucukan dan jenis burung lainnya. Burung liar merupakan salah satu sumber virus ND yang dapat menyebarkan virus ke unggas peliharaan. Penelitian ini bertujuan untuk mengetahui titer antibodi terhadap penyakit tetelo pada burung trucukan liar. Sampel yang digunakan adalah serum darah dari 50 ekor burung trucukan liar. Parameter yang diamati adalah titer antibodi dalam serum berdasarkan metode Hirst menggunakan uji Haemagglutination Inhibition (HI) untuk melihat titer antibodi. Untuk menghitung titer virus maka uji Haemaglutination (HA) dilakukan sebelumnya. Untuk memastikan titer antigen yang digunakan adalah $4 \mathrm{HAU}$ dilkukan juga back titrasi sehingga didapatkan nilai virus optimal yang akan dipakai pada uji HI. Hasil penelitian menunjukkan 45 dari 50 sampel (90\%) mempunyai antibodi positif terhadap ND, dengan titer berkisar 21$2^{9}$. Berdasarkan hasil yang diperoleh dapat disimpulkan bahwa 90\% burung trucukan di Kabupaten Aceh Besar sudah pernah terpapar ND, tetapi hanya $80 \%$ yang memiliki titer antibodi yang dapat melingdungi terhadap serangan virus ND. Oleh sebab itu dapat disimpulkan bahwa burung trucukan liar dengan titer antibodi yang protektif berarti sudah pernah terpapar virus ND sebelumnya akan berpotensi sebagai pembawa virus yang dapat ditularkan ke unggas peliharaan masyarakat di sekitarnya.
\end{abstract}

Kata kunci : Burung liar, Haemagglutination inhibition, Newcastle disease, Uji serologi, Zoonosis.

\begin{abstract}
Trucukan bird (Pycnonotus goiavier) is one of the wild chirping birds that is often preserved because of its tuneful chirp. Newcastle disease (ND) is an acute infectious disease that attacks trucukan birds and other bird species. Wild birds are one of the source of virus that can spread virus to domestic poultry. This study aims to find out the titer antibody against Newcastle disease in wild trucukan birds. The sample used was blood serum from 50 wilds trucukan birds. The parameters observed were the titer of antibody in the serum based on Hirst method using Haemagglutination Inhibition test to measure the antibody titer. To calculate the virus titer, the Haemagglutination (HA) test was performed previously to ensure that the antigen titer used is $4 \mathrm{HAU}$, a back titration is also carried out, so that the optimal virus value is obtained which will be used in the $\mathrm{HI}$ test. The results showed 45 out of 50 samples $(90 \%)$ was positive for antibodies againt ND, with the range of titer is $2^{1}$ to $2^{9}$. Based on the results obtained, it can be concluded that $90 \%$ of the Trucukan birds in the Regency of Aceh Besar have been exposed to ND, but only 80\% have protective antibody titer. Therefore, it can be concluded that wild trucukan birds with protective antibody titers, meaning that they have been exposed to the ND virus before, will have the potential to be carriers of the virus that can be transmitted to domesticated poultry in the surrounding community.
\end{abstract}

Key words: Haemagglutination inhibition, Newcastle disease, Wild birds, Serology test, Zoonotic 


\section{PENDAHULUAN}

Burung atau aves adalah jenis hewan bertulang belakang (vertebrata) yang memiliki bulu dan sayap. Burung termasuk hewan yang berkembang biak dengan cara bertelur (ovipar). Spesies burung dapat diperkirakan terdapat sekitar 8.800-10.200 spesies di seluruh dunia dan sekitar 1.500 spesies di antaranya ditemukan di Indonesia, dari 1500 spesies tersebut 465 spesies dapat ditemukan di Pulau Sumatera. Burung merupakan hewan berdarah panas sama seperti mamalia (Primark et al., 1998; Hidayat et al., 2017). Habitat burung meliputi rawa-rawa, laut ataupun tengah laut, pesisir pantai, hutan tropis, padang rumput, gua-gua batu, pemukiman, bahkan di wilayah perkotaan (Kuswanda, 2010).

Menurut paruhnya burung dibedakan menjadi burung paruh bengkok dan non paruh bengkok yang biasa disebut burung pekicau (Prakosa dan Kurniawan, 2015). Salah satu burung pekicau adalah burung trucukan (Pycnonotus goiavier). Burung trucukan lebih banyak menghabiskan waktu untuk mencari makanan di daratan dengan jenisnya sendiri maupun dengan jenis cerucuk yang lain, atau dengan jenis burung yang lain. Burung ini selalu hidup berkelompok baik saat mencari makan ataupun ketika bertengger (Badrunasar, 2013).

Burung dapat terinfeksi oleh beberapa penyakit seperti Avian Influenza, Cronic Respiratory disease (CRD), Corryza, dan Newcastle disease (ND) (Nurcahya, 2017). Penyakit ND dapat menginfeksi unggas peliharaan maupun unggas liar dan juga berpotensi zoonosis.

Penyakit tetelo atau ND merupakan salah satu penyakit menular pada unggas. Penyakit ini memiliki karakteristik mudah menular, mudah menyebar dan dapat menyerang unggas pada semua umur. Penyakit ND disebabkan oleh virus ND atau strain virulen dari avian paramyxovirus tipe 1 (APMV-1) (Fenner et al., 1993). Virus ND mempunyai aktifitas biologik yaitu kemampuan untuk mengaglutinasi dan menghemolisis eritrosit atau melakukan fusi dengan sel-sel tertentu, mempunyai kemampuan neuraminidase dan kemampuan untuk bereplikasi di dalam sel-sel tertentu (Tabbu, 2000).

Kerugian akibat penyakit ND disebabkan karena angka kematian (mortalitas) maupun angka kesakitan (morbiditas) pada ternak unggas yang sangat tinggi. Mortalitas maupun morbiditas dapat mencapai 30\% pada infeksi virus strain lentogenik, 50\% pada strain mesogenic, dan 50\%-100\% pada strain velogenik (Tabbu, 2000). Beberapa penelitian tentang keberadaan kasus ND di Aceh telah dilakukan oleh Darniati et al., 2015 dan Etriwati et al., 2017.
Sepanjang tahun 2012 penyakit pernafasan masih mendominasi perunggasan Aceh. Penyakit ND menjadi perhatian utama pemerintah di Kabupaten Aceh Besar selain Avian Influenza. Selama tahun 2011, hampir seluruh Kecamatan dalam wilayah Aceh Besar mengalami kasus ND dengan rata-rata 100 kasus di tiap kecamatan. Usaha penanggulangan dilakukan dengan melaksanakan vaksinasi dan pengawasan lalu lintas unggas dari daerah-daerah yang diduga tercemar virus ND (Dinas Peternakan Kabupaten Aceh Besar, 2012).

Penelitian tentang ND pada burung merpati telah dilakukan oleh Erina et al 2018 dan AK et al 2019. . Burung liar sebagai sumber penular penyakit sudah banyak diteliti sebelumnya (Brown et al., 2017).Namun pada burung trucukan masih sangat terbatas informasi tentang penyakit ND. Oleh sebab itu, maka perlu dilakukan penelitian tentang deteksi antibodi terhadap virus ND padaburung trucukan.

\section{BAHAN DAN METODE}

\section{Metode Penelitian}

Metode penelitian ini berupa observasional lapangan dan cross sectional study yang dikerjakan dengan uji $\mathrm{HI}$ test sesuai Hirst.

\section{Prosedur Penelitian}

\section{Pengambilan Sampel}

Sampel yang digunakan adalah serum darah dari 50 ekor burung trucukan (Pycnonotus goiavier). Burung trucukan yang berasal dari sawah di daerah Saree, Kecamatan Lembah Seulawah, Kabupaten Aceh Besar, ditangkap dengan jaring dan diambil darahnya.Pengambilan darah dilakukan melalui vena brachialis.

\section{Pengukuran Titer Antibody}

Darah sampel yang telah diperoleh dibiarkan selama 4-5 jam pada suhu ruangan hingga diperoleh serum yang bening. Kemudian, serum yang terbentuk dipindahkan ke microtube. Uji hemaglutinasi dilakukan untuk melihat titer virus, kemudian dilakukan back titrasi untuk memastikan titer antigen yang digunakan adalah 4 HAU. Selanjutnya dilakukan Uji Hemaglutinasi inhibisi untuk menentukan titer antibodi. Sampel serum terlebih dahulu dimasukkan ke dalam waterbath pada suhu $56^{\circ} \mathrm{C}$ selama 30 menit untuk menginaktifkan komplemen sebelum dilakukan uji Hemaglutinasi Inhibisi. 


\section{Analisis Data}

Data hasil pengamatan dianalisis secara deskriptif dan disajikan dalam bentuk tabel sesuai yang tertera pada Tabel 1 dan Gambar 3.

\section{HASIL}

Penelitian deteksi antibodi terhadap virus Newcastle disease pada burung trucukan (Pycnonotus goiavier) dilakukan dengan menggunakan uji Hemaglutinasi Inhibisi. Prinsip uji $\mathrm{HI}$ adalah hambatan aglutinasi RBC akibat terikatnya virus (antigen) dengan antibodi spesifik yang ditandai dengan adanya endapan eritrosit pada sumur microplate untuk menentukan nilai titer antibodi. Serum dinyatakan positif dan protektif apabila menunjukkan titer antibodi $\geq 2^{4}$ (OIE, 2012).

Hasil pemeriksaan dari 50 sampel serum darah burung trucukan yang diambil dari sawah di daerah Saree, Kecamatan Lembah Seulawah, Kabupaten Aceh Besar dapat dilihat pada Tabel 1.

Berdasakan hasil pemeriksaan, 45 dari 50 sam pel (90\%) dinyatakan positif adanya antibody terhadap virus ND dengan kisaran titer $2^{1}-2^{9}$, untuk anti bodi yang protektif sebanyak 40 sampel $(80 \%)$ dan yang non-protektif adalah 5 sampel (10\%), sedangkan sampel yang negatif hanya 5 dari 50 sampel (10\%). Berdasarkan hasil yang diperoleh dapat dinyatakan bahwa 90\% burung di daerah Saree, Kecamatan Lembah Seulawah, Kabupaten Aceh Besar sudah pernah terpapar virus ND.

Hasil uji back titrasi dapat dilihat pada Gambar 1. Selanjutnya dilakukan uji HI pada serum kontrol positif dan negatif untuk memastikan bahwa hasil yang diperoleh pada penelitian ini sesuai dengan standard yang ditetapkan OIE (2012).
Hasil untuk serum positif (Gambar 3) dan negative dapat dilihat pada Gambar 4 (A-B) dan (G-H). Interpretasi hasil positif dapat dilihat pada Gambar 3, terjadi hambatan aglutinasi karena adanya antibodi pada serum darah burung trucukan. Hambatan aglutinasi terjadi pada baris A, B, C dan D sampai kolom ke $6\left(2^{6}\right)$, pada baris $E$ dan $F$ sampai kolom ke $5\left(2^{5}\right)$, dan pada baris $\mathrm{G}$ dan $\mathrm{H}$ sampai kolom $7\left(2^{7}\right)$. Sumur 11 sebagai kontrol positif yang ditandai dengan adanya endapan eritrosit (tears drop).

\section{PEMBAHASAN}

Sampel negatif dapat disebabkan karena burung belum pernah terinfeksi oleh virus ND sehingga tidak ditemukan antibodi, namun bisa juga karena burung tersebut sudah terinfeksi virus ND tetapi antibodi belum terbentuk atau masih sedikit sehingga tidak cukup untuk memberikan hasil reaksi positif pada uji HI. Kemungkinan lain dapat terjadi bahwa burung sudah pernah terinfeksi oleh virus ND namun kejadiannya sudah lama sekali sehingga antibodi dalam tubuhnya sudah menurun atau tinggal sedikit sehingga tidak mampu memberikan hasil reaksi positif pada uji HI (Andrewes dan Pereira, 1972).

Menurut Amanu dan Rohi (1989), antibodi mulai terdeteksi dalam serum memerlukan waktu 6 sampai 10 hari dan akan mencapai puncaknya pada 3 sampai 4 minggu, kemudian menurun 3 sampai 4 bulan dan tidak terdeteksi setelah 8 sampai 12 bulan setelah paparan.Titer antibodi yang didapat ditentukan berdasarkan atas hambatan aglutinasi eritrosit oleh antibodi pada pengenceran serum (antibodi) tertinggi yang masih mampu mengikat antigen (pada konsentrasi 4 HA Unit) dan menghambat aglutinasi eritrosit (Janovie et al, 2014). Maka dari itu harus dilakukan back titrasi untuk memastikan bahwa antigen yang

Tabel 1 Hasil uji HI untuk pemeriksaan antibodi terhadap virus ND pada serum burung trucukan berdasarkan titer antibody

\begin{tabular}{cllc}
\hline Titer Antibodi & \multicolumn{1}{c}{ No. Sampel } & \multicolumn{1}{c}{ Interpertasi } & Persentase \\
\hline $2^{\circ}$ & \multicolumn{1}{c}{$33,36,40,46,47$} & Negatif (Non protektif) & $10 \%$ \\
\hline $2^{1}$ & 9 & Positif (Non protektif) & $2 \%$ \\
$2^{3}$ & $13,15,41$ & Positif (Non protektif) & $8 \%$ \\
$2^{4}$ & $2,10,11,14,37,39,42,44,45,49$ & Positif (Protektif) & $20 \%$ \\
$2^{5}$ & $1,3,4,5,6,7,8,12,16,18,31$ & Positif (Protektif) & $22 \%$ \\
$2^{6}$ & $17,21,22,23,24,28,29,30,38,46,50$ & Positif (Protektif) & $22 \%$ \\
$2^{7}$ & $19,25,27,32$ & Positif (Protektif) & $8 \%$ \\
$2^{8}$ & 26 & Positif (Protektif) & $2 \%$ \\
$2^{9}$ & $20,34,35$ & Positif (Protektif) & $6 \%$ \\
\hline
\end{tabular}


176 | Erina et al.

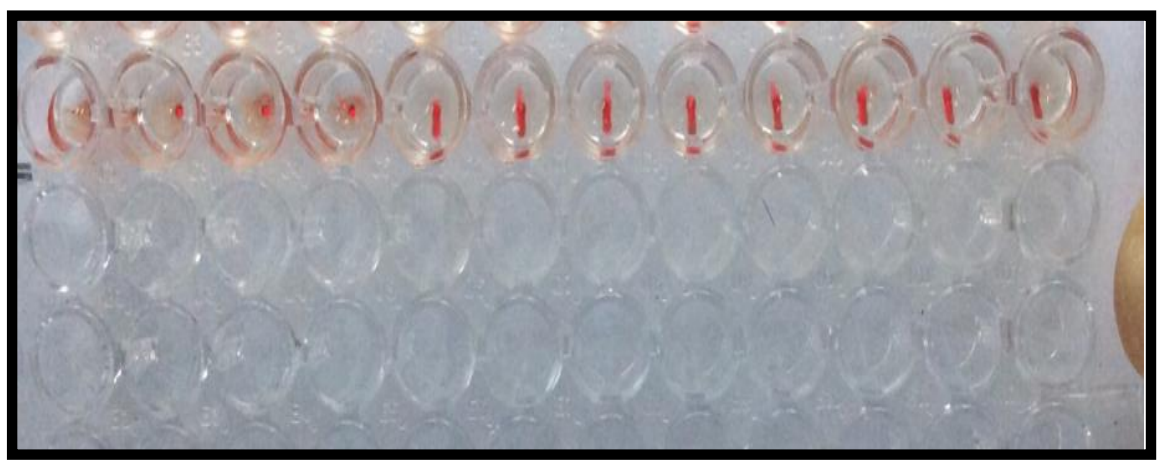

Gambar 1 Hasil back titrasi antigen (virus ND) yang digunakan pada uji HI

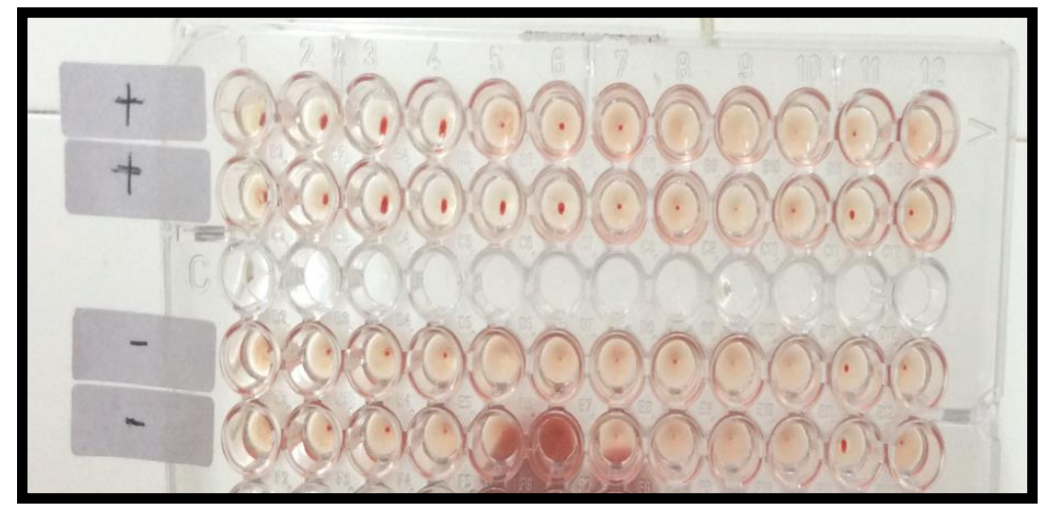

Gambar 2 Hasil uji HI terhadap kontrol positif dan negatif virus ND

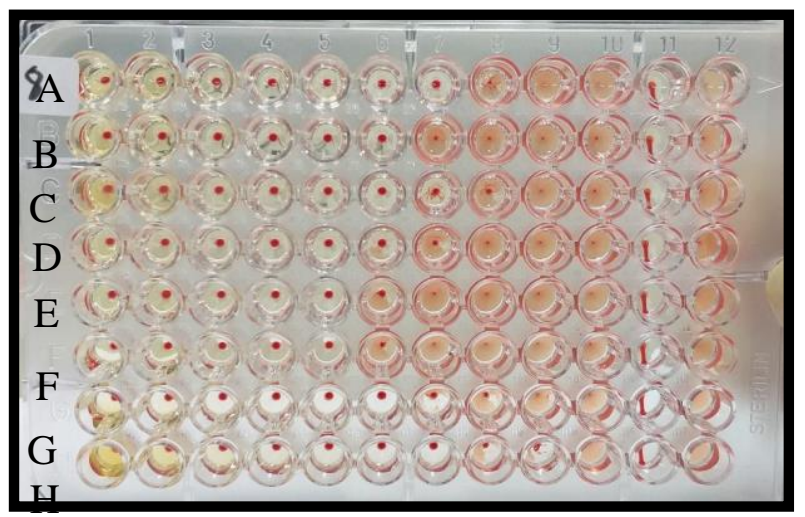

Gambar 3 Hasil positif uji HI terhadap virus ND pada serum burung trucukan

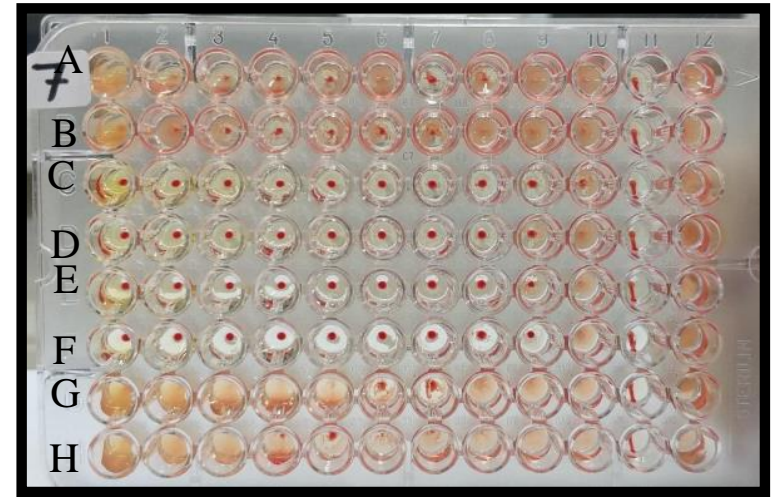

Gambar 4 Hasil negatif uji HI terhadap virus ND pada serum burung trucukan (A-B dan G-H) 
digunakan pada uji HI bernilai 4 HA Unit. Prinsip pengerjaan back titrasi sama dengan uji Hemaglutinasi $(\mathrm{HA})$.

Interpretasi hasil negatif dapat dilihat pada Gambar 5 di baris $A$ dan $B$ dan juga baris $\mathrm{G}$ dan $\mathrm{H}$ tidak terbentuk endapan eritrosit, reaksi tersebut disebabkan tidak adanya antibodi yang dapat menghambat reaksi pada serum darah burung trucukan. Sumur 11 sebagai kontrol positif yang ditandai dengan adanya endapan eritrosit (tears drop). Dari 50 sampel serum burung trucukan, didapatkan titer negatif sebanyak 5 sampel (10\%) dengan titer $2^{\circ}$, sampel serum burung yang negatif menunjukkan bahwa burung tidak memiliki antibody terhadap virus ND.

Sampel yang dinyatakan positif terjadi hambatan aglutinasi karena adanya ikatan antara antibodi dengan antigen (virus ND), akibatnya virus ND tidak dapat mengaglutinasi eritrosit. Hal tersebut dapat dilihat melalui endapan eritrosit yang terlihat seperti tetes air mata pada dasar microplate. Disamping itu serum antibodi spesifik terhadap virus ND bersifat dapat menghambat reaksi hemaglutinin.

Keberagaman nilai titer antibodi dapat terjadi akibat beberapa faktor diantaranya jumlah virus yang menginfeksi, dan tingkat kebal individu yang berbeda. Jumlah virus yang rendah tidak dapat merangsang sel sel imunokompeten. Variasi tanggap kebal tiap individu yang berbeda akan mempengaruhi kekebalan yang dihasilkan (Komariyah et al., 2018). Titer antibodi tertinggi yang didapat adalah $2^{9}$, hal tersebut dapat terjadi karena kemungkinan burung tersebut terinfeksi oleh virus ND namun sebelumnya burung tersebut sudah memiliki antibodi ND.

Penularan virus ND dapat terjadi secara langsung dari satu hewan ke hewan lainnya melalui kontak, sekresi dan eksresi dengan hewan yang terinfeksi, serta bangkai penderita ND. Penyebaran penyakit ND dapat juga melalui burung peliharaan ataupun burung liar yang berada di sekitar kandang atau masuk kedalam kandang (Akoso, 1998). Menurut Syukron (2013) Penyebaran virus ND melalui udara dapat mencapai radius $5 \mathrm{~km}$, hal ini sangat mendukung terjadinya paparan virus secara alami pada burung maupun unggas liar dan kemungkinan dapat terjadi pada sampel yang digunakan yaitu burung trucukan yang merupakan burung liar atau tidak dipelihara.

Tingkat kejadian ND terdapat di seluruh dunia cukup tinggi, termasuk di Indonesia (Ideris, 1993). Penyakit ini ditemukan pertama kalinya oleh Kreneveld di Indonesia pada tahun 1926 (Direktorat Jendral Peternakan dan kesehatan Hewan, 2014). Penyakit ND di Indonesia menyebar ke berbagai daerah baik di Jawa maupun du luar Jawa hingga saat ini hampir seluruh wilayah Indonesia merupakan daerah tertular dan belum ada satu daerah yang bebas dari ND (Tarmudji, 2005).

Berdasarkan hasil penelitian disimpulkan bahwa Sembilan puluh persen dari 50 sampel serum darah burung trucukan (Pycnonotus goiavier) di Kabupaten Aceh Besar, positif terhadap antibodi virus ND dengan titer $2^{1}-2^{9}$, dan hanya $80 \%$ memiliki titer antibodi yang protektif $\left(\geq 2^{4}\right)$.

\section{DAFTAR PUSTAKA}

AK, M. D., Setiyaningsih, S., \& Sudirman, I. (2019). Identification and Molecular Characterization of Newcastle Disease Virus Circulates in some districts in Aceh. Jurnal Kedokteran Hewan March, 13(1), 10-14.

Akoso BT. 1998. Kesehatan Unggas. Penerbit Kanisius, Yogyakarta.

Amanu S, Rohi OK. 2005. Newcastle Disease Other Avian Paramyxoviruses Infections In Disease of Poultry Twelfth Edition. Iowa State University Press, USA.

Andrewes SC, Pereira HG. 1972. Viruses Of Vertebrates $3^{\text {rd }}$. Publised in the United States of America by The Williams and Walkins Company, Baltimore.

Badrunasar A. 2013. 9 Jenis Burung Pekicau Arboretum Balai Penelitian Teknologi Agroforestry. Balai Penelitian Teknologi Agroforestry, Ciamis.

Brown, V. R., \& Bevins, S. N. (2017). A review of virulent Newcastle disease viruses in the United States and the role of wild birds in viral persistence and spread. Veterinary research, 48(1), 1-15.

Darniati, D., Setiyaningsih, S., \& Indrawati, A. (2015). Deteksi molekuler dan keragaman virus Newcastle disease pada ayam kampung di wilayah Aceh. Jurnal Kedokteran Hewan-Indonesian Journal of Veterinary Sciences, 9(2).

Dinas Peternakan Kabupaten Aceh Besar. 2012. Laporan Tahunan Dinas Peternakan Tahun 2011, Aceh Besar.

Direktorat Jendral Peternakan dan Kesehatan Hewan. 2014. Manual Penyakit Unggas. Penerbit Kementrian Pertanian, Jakarta.

Erina, E., Harahap, A. A., Abrar, M., Helmi, T. Z., Salim, M. N., \& Rinidar, R. (2018). DETEKSI ANTIBODI VIRUS AVIAN INFLUENZA SUBTIPE H5N1 PADA BURUNG MERPATI (Columba livia)(Detection Antibodies of Avian Influenza Virus Subtype $\mathrm{H}_{5} \mathrm{~N}_{1}$ on Pigeon (Columba livia)). Jurnal Ilmiah Mahasiswa Veteriner, 3(1), 16-23. 
178 | Erina et al.

Etriwati, R. D., Handharyani, E., \& Setiyaningsih, S. (2017). Studi histopatologi limpa dan bursa fabricious ayam berpenyakit tetelo (Newcastle Disease) pada kasus lapang. J Veteriner, 18, 510-515.

Fenner FJ, Gibbs EPJ, Murphy FA, Rott R, Studert MJ, White DO. 1993. Virologi Veteriner. Academic Press Inc, California.

Hidayat R, Rifanjani S, Wahdina. 2017. Studi keanekaragaman jenis burung diurnal di hutan sebadal taman nasional gunung palung kabupaten kayong utara. Jurnal Hutan Lestari, 5(3):696-703.

Ideris A. 1993. Poultry diseases in Asia/Pacific region The $X^{\text {th }}$ International Congress of the World Veterinary Poultry Association, Sydney.

Janovie A, Rusdi, Supiyani, A. 2014. Uji efektivitas vaksin flu burung subtipe h5n1 pada ayam kampung di Legok Tangerang, Banten. BIOMA, 10(2).

Komariyah S, Rahmahani J, Agustono B. 2018. Pengaruh ekstrak buah pare (momordica charantia) terhadap titer antibodi ayam broiler yang divaksin Newcastle disease. Jurnal Medik Veteriner, 1(3):128-133.

Kuswanda W. 2010. Pengaruh komposisi tumbuhan terhadap populasi burung di taman nasional batang gadis sumatera utara. Jurnal Penelitian Hutan dan Konservasi Alam, 7(2):193-213.Nurcahya ED. 2017. Klasifikasi penyakit ayam menggunakan metode support vector machine. Jurnal Ilmiah Pendidikan Teknik Elektro, 2(1):45-54.

OIE [Office International des Epizootie]. 2012. Newcastle Disease (chapter 2. 3.14). OIE Terrestrial Manual 2012.1-12.

Prakosa BH, Kurniawan N. 2015. Studi burung-burung yang diperdagangkan di pasar burung splendid kota malang. Jurnal Biotropika, 3(1):7-8.

Primark RB, Supriatna J, Indrawan M, Kramadibrata P. 1998. Biologi Konservasi. Yayasan Obor Indonesia, Jakarta.

Syukron MU, Suartha IN, Dharmawan NS. 2013. Serodeteksi penyakit tetelo. Indonesia Mediscus Veterinus, 2(3):360-368.

Tabbu CR. 2000. Penyakit Ayam dan Penanggulangannya: Penyakit Bakterial, Mikal, dan Viral. Penerbit Kanisius, Yogyakarta.

Tarmudji. 2005. Penyakit pernafasan pada ayam, ditinjau dari aspek klinik dan patologik serta kejadiannya di Indonesia. Wartazoa, 15(2): 72-83. 